\title{
Mass Balance of Plastic Waste Conversion to Fuel Oil- A case in
}

\section{Uganda}

\author{
Prosper Achaw Owusu ${ }^{1}$, Noble Banadda ${ }^{1} \&$ Nicholas Kiggundu ${ }^{1}$ \\ ${ }^{1}$ Department of Agricultural and Bio-systems Engineering, Makerere University, Kampala, Uganda \\ Correspondence: Prosper Achaw Owusu, Department of Agricultural and Bio-systems Engineering, Makerere \\ University, P.O. Box 7062, Kampala, Uganda. E-mail: oaprospa@gmail.com
}

Received: July 12, 2017

doi:10.5539/jsd.v10n6p41
Accepted: September 12, $2017 \quad$ Online Published: November 29, 2017

URL: https://doi.org/10.5539/jsd.v10n6p41

\begin{abstract}
The current rate of plastic usage and the manner in which they are being disposed of is unsustainable. This is because more resources such as crude oil are utilized for their production and on the other hand, more waste plastics are generated. Since these waste plastics are made from crude oil, there is a high chance that they can be turned back into diesel that can be used to power irrigation pumps, drive engines for transport and industrial purposes among other potential uses. This paper sought to evaluate the pyrolysis of waste plastics to fuel oil potential of Uganda. The estimated waste plastics generated in Uganda was quantified as $545851 \mathrm{~kg} / \mathrm{day}$. In this study, mass balance estimation indicated that the initial feed of $545851 \mathrm{~kg}$ of waste plastics yields $451419 \mathrm{~kg}$ liquid fuel using an appropriate technology for pyrolysis. The production potential of the gaseous and char fractions was calculated to be 50764 and $43668 \mathrm{~kg}$ in a day, respectively. This estimated amount has the potential to power approximately 234 small portable threshers of 5-7 horsepower. A total of 365000 tonnes of fresh paddy can be threshed using these threshers. The gaseous fraction also has the potential to be used as a source of fuel for cooking. This is particularly important for postharvest handling and food security in Uganda as well as development of waste to energy technologies such as pyrolysis.
\end{abstract}

Keywords: Mass balance analysis, waste plastics, pyrolysis, sustainability, waste to energy technologies

\section{Introduction}

\subsection{The Waste Plastic Situation}

There have been many major changes on the surface of the planet in the last 50 years. But one of the most instantly observable wastes on the environment is the ubiquity and abundance of waste plastics (Barnes, Galgani, Thompson, \& Barlaz, 2009; Eriksen et al., 2014; Sharma, Moser, Vermillion, Doll, \& Rajagopalan, 2014). Global usage of plastics is increasing (Thompson, Moore, vom Saal, \& Swan, 2009). Plastics are used in many applications (Bashir, 2013) because of their versatility, light weight and also easy to manufacture (Andrady \& Neal, 2009). Plastics are used extensively in automobiles (Gerrard \& Kandlikar, 2007; Mazzanti \& Zoboli, 2006; Smink, 2007), building and constructions (Cleetus, Thomas, \& Varghese, 2013), packaging (Al-Salem, Lettieri, \& Baeyens, 2009), bags (Bashir, 2013) and phones (Kasper et al., 2011; Yamane, de Moraes, Espinosa, \& Tenório, 2011) and computers (Balakrishnan, Anand, \& Chiya, 2007; Guo, Guo, \& Xu, 2009; Hall \& Williams, 2007). As a consequence, the production of plastics has increased substantially over the last 60 years (Thompson et al., 2009). In 2004, the world's total production of plastics was estimated at 225 million tonnes. By 2014, global production of plastics increased to 311 million tonnes, representing a rapid increase of $38 \%$ (PlasticsEurope, 2015). Other drivers responsible for the steady growth of plastics are its user-friendly design, and low costs (Bashir, 2013; Panda, Singh, \& Mishra, 2010; B. Singh \& Sharma, 2007) and also higher pursuit of life (United Nations Environment Programme [UNEP], 2014). About one third of the current production of plastics is used for packaging and other short-lived applications (Thompson et al., 2009). This current rate of plastic growth makes it unsustainable (Hopewell, Dvorak, \& Kosior, 2009; Jambeck et al., 2015). More resources are needed to meet the increased demand of plastic, and conversely, more plastic waste is being generated (UNEP, 2009).

Plastic waste management is a serious environmental and public health issue in most cities all over the world. Efforts to manage plastic wastes are always overwhelmed by the ever increasing urbanization (Troschinetz \& Mihelcic, 2009) and consumption of plastic materials (Nabukeera Madinah \& Boerhannoeddin, 2014) coupled 
with low levels of infrastructure to handle wastes. A definite contrast exists between usage of waste plastics in Europe and developing countries. In Europe, plastic waste is increasingly recognized as a resource (European Commission [EC], 2010). In 2014, 69.2\% was recovered through recycling and energy recovery processes while $30.8 \%$ still went to landfill (PlasticsEurope, 2015). However, in Kampala, only 2\% of about 62050 tonnes of plastic wastes generated annually are recycled (Tukahirwa, Mol, \& Oosterveer, 2010). The drainage system in Uganda is in the same way choked with plastic materials such as ice cream wrappers, polyethylene-film bags and other plastic materials.

\subsection{Recent Scholarship on the Management of Waste Plastics}

Currently, there are three most common ways to utilize plastic wastes: landfilling, incineration with or without energy recovery and recycling (Ali, Garforth, Harris, Rawlence, \& Uemichi, 2002). The largest amount of plastic wastes is disposed of by landfilling (65-70\%) and incineration (20-25\%). Recycling is only about $10 \%$. Moreover, the problem of plastic wastes cannot be resolved by landfilling and incineration, because suitable and safe depots are expensive, and incineration stimulates the growing emission of harmful, greenhouse gases (Chung et al. 2003; Sarker and Rashid 2013). Chemical recycling can either be a thermal or catalytic process by which waste plastics are converted into petrochemical products (Almeida \& Marque, 2015). Since plastics are made from crude oil, there are high chances that these plastics can be turned back into diesel or petrol to power vehicles through a process called pyrolysis. Fuel oil, gas, wax and sometimes char are the products of pyrolysis (Chandrasekaran, Kunwar, Moser, Rajagopalan, \& Sharma, 2015; Demirbas, 2004; Walter Kaminsky \& Zorriqueta, 2007; Panda et al., 2010). The fraction of each product depends on the composition of plastics, type of reactor, temperature and heating rates (Bajus, 2011; Kluska, Klein, Kazimierski, \& Kardas, 2014). The yield of liquid oil from the pyrolysis of waste plastics found in literature is reported to be more than $80 \%$ (weight) (R. K. Singh \& Ruj, 2016; Wong, Ngadi, Abdullah, \& Inuwa, 2015). The oil products can either be used as a feedstock for plastic production or as a fuel to run engines. This is one of the best ways to utilize waste polymers ( Sarker \& Rashid, 2013; W. Kaminsky, Predel, \& Sadiki, 2004). The prospects of turning plastic waste into a resource is attractive for a developing country like Uganda where local authorities struggle to cope with the ever increasing volumes of such materials in public areas. It is against this background that this study aims at evaluating waste plastics to fuel oil potential of Uganda.

\section{Composition of Municipal Solid Waste in Developing World}

Municipal Solid Waste (MSW) is made up of wastes from durable goods (e.g., tires, furniture), non-durable goods (e.g., newspapers, plastic plates/cups), containers and packaging (e.g., milk cartons, plastic wrap), and other wastes (e.g., yard waste, food) (Center for Sustainable Systems [CSS], 2015). It is necessary to present data on waste generation and its composition in order to understand the current situation of municipal solid waste management (Chen, Geng, \& Fujita, 2010). Sources of MSW are residential, commercial, institutional and municipal services. Residential and commercial solid wastes are made up of both organic and inorganic wastes. Organic waste materials include food wastes, papers, leathers, yard wastes, ashes, and wood. The inorganic wastes comprise of glasses, tin cans, crockery, dirts and metals. Other wastes from commercial and residential sources are waste oil, electronics, batteries, tires and paints. Institutional sources of solid wastes include prisons, hospitals, universities and schools, and centers. Other community wastes result from street sweepings, dead animals, abandoned automobiles, tree cuttings and roadside litter (Guangyu, 2010). The composition of MSW is city specific (Guangyu, 2010). The major factors that contribute to the amount of MSW are population growth, standard of living and diet habits (Kinobe, Niwagaba, Gebresenbet, Komakech, \& Vinnerås, 2015; Komakech, 2014; Troschinetz \& Mihelcic, 2009). A number of authors (Komakech et al., 2014; Miezah, Obiri-Danso, Kadar, Fei-Baffoe, \& Mensah, 2015; Nabukeera Madinah \& Boerhannoeddin, 2014) have provided several overviews on the composition of MSW in sub-Saharan Africa. The per capita generation of waste plastic is estimated as $0.056 \mathrm{~kg} /$ day. Table 1 shows the estimated daily waste plastics in major districts in Uganda. 
Table 1. Estimated amount of plastics generated in major districts in Uganda

\begin{tabular}{lll}
\hline Districts & Population & Waste plastic $(\mathrm{kg} /$ day $)$ \\
\hline Wakiso & 2007700 & 112431 \\
Kampala & 1516210 & 84908 \\
Kibaale and Iganga & 1295102 & 72526 \\
Arua and Kasese & 1487218 & 83284 \\
Mubende and Mukono & 1288636 & 72164 \\
Tororo and Rakai & 1044386 & 58486 \\
Hoima and Kabale & 1108063 & 62052 \\
Total & $\mathbf{9 7 4 7 3 1 5}$ & $\mathbf{5 4 5 8 5 1}$ \\
\hline
\end{tabular}

\section{Solid Waste Management in Developing Countries}

Municipal solid waste management (MSWM) has been one of the most serious environmental problems in countries without proper waste management system (Achankeng, 2003; Chen et al., 2010). In Uganda, both the formal and informal sectors are involved in solid waste management. Waste management begins with the collection of the waste. However, in developing countries, due to high population growth coupled with lack of available resources (money and infrastructures) to provide a better SWM leads to insufficient waste collection, open dumping and indiscriminate disposal of waste along the streets (Sembiring \& Nitivattananon, 2010). In Kampala, the capital of Uganda, the collection, transportation and disposal of MSW is now a shared responsibility of the Kampala City Council Authority (KCCA) and private sector players. As a matter of fact, KCCA plans to withdraw from solid waste collection such that it is a private sector led service to city dwellers.

\subsection{Waste Collection}

Road-side and household and community collections are the adopted methods of waste collection in residential areas in Kampala. In road-side waste collection, residents sort recyclable items into particular collection containers offered by the waste collection authorities. In the household collection system, a bell is rang to remind residents to send their waste to the street level for disposal (Zhang, Tan, \& Gersberg, 2010). The household system of waste collection have been taken out and replaced with a new system. Residents are now advised to place their wastes in dustbins and bags outside their houses for collection. Also, households send their wastes to community collection points such as skips and bunkers and the waste is later transported by a truck to a landfill site called Kiteezi, which is privately owned by Otada Construction Company (Komakech et al., 2014) and other waste disposal sites. The other waste disposal sites are owned and operated by the urban councils and are poorly managed. This can be attributed to the fact that most resources are assigned to only waste collection and not to disposal management. The highest collection level is normally done by private companies. The urban poor receive very low if not no waste collection facilities due to inaccessible roads, unplanned facilities and disregard by the urban authority (Okot-Okumu \& Nyenje, 2011). The collection of MSW is very important when it comes to its management. With no labeled street numbers or numbered houses, waste collection is very hard and any traceability is not possible.

\subsection{Waste Separation and Recycling}

MSW is principally composed of organic, recycling and non-recyclable wastes (Sembiring \& Nitivattananon, 2010; Zhang et al., 2010). Waste sorting, separation and classification are currently not done at disposal point. Sometimes residents volunteer to participate in the sorting out. Residents then sell the recyclables from the wastes to itinerant buyers (door to door buyers) or exchange items such as containers, footballs, and cutlasses, who in turn sell them to factories as raw or processed materials. The mixture that ends up at the various landfill sites are collected and sorted out by waste collectors patrolling the sites (Komakech, 2014). The separation and sorting out allows recovery and therefore reduces the amount of waste that is sent to landfill sites (Fauziah \& Agamuthu, 2012). Generally speaking, weak rules and regulations enforcement, poverty and lack of education hamper waste separation and recycling in Kampala.

\subsection{Landfilling}

The management of MSW in most developing countries is by landfilling. This is because it is very cheap and can accommodate large amount of any kind of waste (Zhang et al., 2010). Figure 1 shows scavengers at Kiteezi 
landfill site. The waste dumping site at Kiteezi has been upgraded to sanitary landfill. Although, it has inbuilt leachate treatment plant, there is a leakage and this pollutes surface and groundwater (Nabukeera Madinah \& Boerhannoeddin, 2014). 55\% of the wastes generated are successfully dumped to the landfill site at Kiteezi. The remaining 45\% remains mismanaged (Nabukeera Madinah \& Boerhannoeddin, 2014).

\subsection{Overview of Energy Recovery from Waste in Developing Countries}

The generation of energy from waste is a valuable option in choosing MSW management technique. However, due to the high capital cost of waste-to-energy (WtE) technologies, they are normally adopted in most advanced countries. China, for instance, installed approximately $100 \mathrm{WtE}$ plants as at 2009 (Dong, 2011). This has helped improved public health in the rural areas of China. The Uganda Government set a target to produce $30 \mathrm{MW}$ from solid waste by the end of the year 2017 (El-Agroudy, Warith, \& El-Zayat, 2015). The government of Uganda also set a target to install about 100000 family-sized digesters by the year 2017 (Veit, Excell, \& Zomer, 2011). So far, about half of the 500 installed biogas digesters are in operation (Owusu \& Banadda, 2017; UBOS, 2010). The rate of adoption of biogas technology in Uganda is slow due to lack of technical capacity for installation and maintenance and high initial costs of installation (Okello, Pindozzi, Faugno, \& Boccia, 2013).

Incineration with energy recovery as a waste management technique can be used to recover energy and many attempts have been made to promote it in sub-Sahara African cities such as Lagos. However, organic waste makes a bigger fraction of the MSW and it has low calorific value and high moisture content (Narayana, 2009). These and other factors such as release of harmful greenhouse gases make incineration unsustainable for developing cities in sub-Sahara Africa (Giusti, 2009). Incineration without energy recovery is a common practice in developing countries. This is done purposely to reduce the amount of organic wastes in MSW before disposal (Dhokhikah \& Trihadiningrum, 2012). Waste minimization principles such as the 3Rs (reduce, reuse and recycle), composting and anaerobic digestion that offer social, environmental and economic benefits to the urban community should be encouraged in developing countries. There is also the need to adopt pyrolysis for the treatment of plastic wastes. This process is sustainable in the sense that the process is environmentally friendly, easy to run and requires materials that already exist. These factors make the process more suitable for rural and underdeveloped countries (Joshi \& Seay, 2016).

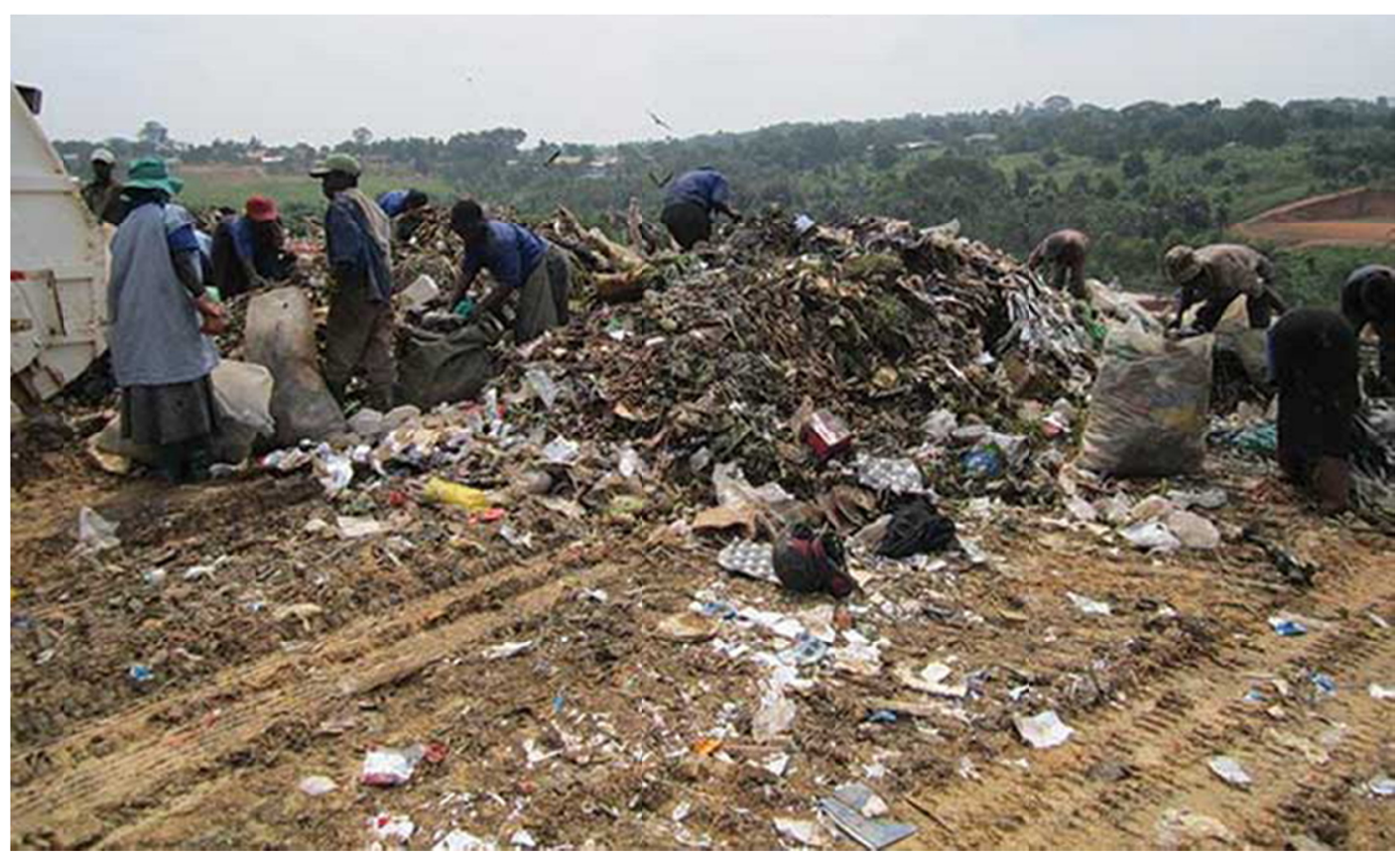

Figure 1. Scavengers at Kiteezi Landfill Site (Komakech et al., 2014)

\section{Mass Balance Calculation and Products Yield During Pyrolysis of Waste Plastics}

For an industrial scale up of pyrolysis process, it is important to know the quantity of plastic waste that is needed to produce a certain amount of fuel oil at optimum conditions (i.e. the quantity of waste plastic needed to produce, say, $1 \mathrm{~kg}$ of fuel oil). Mass balance is always based on the law of conservation of mass. The flow sheet for a mass balance on plastic wastes in a batch reactor is illustrated in figure 2 . 
If it is assumed that there are no leaks and the measurements made are correct, a mass balance for the system can be written in general as in equation (1):

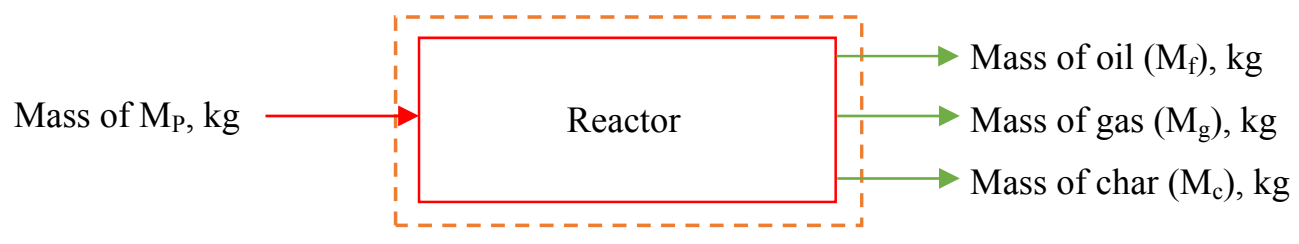

Figure 2. Illustration of mass balance on waste plastics

$$
\begin{gathered}
\text { mass in = mass out } \\
M_{p}=M_{f}+M_{g}+M_{c}
\end{gathered}
$$

Where: Mp-mass of waste plastics, $\mathrm{M}_{\mathrm{f}}$-mass of fuel oil obtained, $\mathrm{M}_{\mathrm{g}}$-mass of uncondensed gas, $\mathrm{M}_{\mathrm{c}}$-mass of char remained in the reactor. It is important to note that all the terms are of the same unit $(\mathrm{kg})$.

According to R. K. Singh \& Ruj (2016), pyrolytic temperature and heating time are the factors that determine the quantity of char remaining in the reactor. Higher heating temperatures and times are associated with the reduction of solid residues in the reactor. The optimum residence time and temperature is reported in literature to be four hours and $400-600{ }^{\circ} \mathrm{C}$ respectively (Joshi \& Seay, 2016).

\subsection{Mass Balance on Plastic Wastes Generated in Uganda}

Previous researchers (Deneve, Joshi, Samdani, Higgins, \& Seay, 2017) carried out a pyrolysis experiment using a batch reactor, which was designed and fabricated by the University of Kentucky Appropriate Technology and Sustainability (UKATS) team. This reactor was designed to be specifically used in underdeveloped countries such as Uganda (Joshi \& Seay, 2016). Results from their experiment indicated that, on average, about $82.70 \%$ of fuel oil can be obtained from the pyrolysis of a mixture of waste plastics at a temperature of $475{ }^{\circ} \mathrm{C}$. The remaining products are uncondensed gas and char. The amount, each of the gaseous and char fractions was not quantified. However, other authors (Grause, Matsumoto, Kameda, \& Yoshioka, 2011) estimated the yield of char from the pyrolysis of a mixture of waste plastics to be $8 \%$ (weight). Also, Sharma et al. (2014) estimated the density of plastic-based diesel (PBD) to be $802 \mathrm{~kg} / \mathrm{m}^{3}$ at a temperature range of $420-440^{\circ} \mathrm{C}$. Based on this data, the mass of fuel oil that can be obtained from various districts in Uganda is summarized and presented in table 2. Polyvinyl chloride (PVC) and polyethylene terephthalate (PET) polymers are included in the estimation. It is therefore necessary to consider a dechlorination step (stepwise pyrolysis) to avoid problems such as the production of hydrochloric acid which corrodes the pyrolysis reactor. Equation 2 can be used to determine the mass of fuel. Equation 3 can also be used to estimate the volume of liquid fuel.

$$
\begin{aligned}
\operatorname{Yield}(w t \%) & =\left(M_{f} / M_{p}\right) 100 \\
\operatorname{Density}\left(\mathrm{kg} / \mathrm{m}^{3}\right) & =\operatorname{mass}(\mathrm{kg}) / \operatorname{volume}\left(\mathrm{m}^{3}\right)
\end{aligned}
$$

Table 2. Estimated mass balance on waste plastics in $\mathrm{kg}$

\begin{tabular}{ccccc}
\hline Districts & Waste Plastic & Fuel oil & Gas & Char \\
\hline Wakiso & 112431.00 & 92980.44 & 10456.08 & 8994.48 \\
Kampala & 84908.00 & 70218.92 & 7896.44 & 6792.64 \\
Kibaale and Iganga & 72526.00 & 59979.00 & 6744.92 & 5802.08 \\
Arua and Kasese & 83284.00 & 68875.87 & 7745.41 & 6662.72 \\
Mubende and Mukono & 72164.00 & 59679.63 & 6711.25 & 5773.12 \\
Tororo and Rakai & 58486.00 & 48367.92 & 5439.20 & 4678.88 \\
Hoima and Kabale & 62052.00 & 51317.00 & 5770.84 & 4964.16 \\
Total & 545851.00 & 451418.78 & 50764.14 & 43668.08 \\
\hline
\end{tabular}

\section{Potential Application of the Estimated Amount of Fuel Oil from Waste Plastics}

Fuel oil from waste plastics has a high heating value (Cleetus et al., 2013; Kumar \& Singh, 2013). The high 
heating value (HHV) of fuel derived from plastic waste is higher than that of conventional petroleum. Sharma et al. (2014) reported that the HHV of plastic-based diesel is $46.16 \mathrm{MJ} / \mathrm{kg}$ while that of conventional fuel oil is $45.15 \mathrm{MJ} / \mathrm{kg}$. This HHV, together with its high density $\left(802 \mathrm{~kg} / \mathrm{m}^{3}\right)$, makes PBD useful in many applications. Additional advantage of the use of PBD is its minimal or sulfur free content which benefits the environment tremendously (Joshi \& Seay, 2016).

Many farmers in Uganda face a lot of challenges in processing their produce after harvest. For example, threshing of rice is predominantly done by beating the harvested crops on tarpaulin or bare ground. This results in heavy contaminations of small stones, straws and weed seeds. For the market value of these crops to go high, these extraneous materials have to be removed. Similarly, milling of maize to produce flour for local food such as posho, ugali, nshima and sadza is not a common practice in some districts. Women and children predominantly use heavy pestles that require a lot of effort to pound maize into fine particles for local food. This is also laborious and time consuming. They resort to these methods because there is no electricity grid available. Lack of electricity grid also has negative effects on farmers' income, health and food security (van Gevelt, Holzeis, Jones, \& Safdar, 2016).

Farmers therefore have to adopt the use of mechanical equipment for threshing. Mechanical threshers reduce drudgery, save time, reduce losses and contamination of foreign materials. These equipment however need to be powered. Small portable threshers that are commonly used in Uganda are powered by 5-7 horse power petrol engines that may use $1 \mathrm{~L}$ of fuel per hour for handling 550-650 $\mathrm{kg}$ of threshed fresh paddy. If a thresher works 8 hours/day for 300 days/year, a total of 1560 tonnes of paddy will be threshed in a year. A total of 234 rice threshers can be powered by 562866 liters of fuel oil from waste plastics. Therefore, 234 rice threshers will handle approximately 365000 tonnes of fresh paddy annually.

On the other hand, the power requirement of hammer mills for grinding maize ranges between two and $50 \mathrm{~kW}$. A $15 \mathrm{~kW}$ hammer mill uses 3 liters of diesel per hour for handling approximately $400 \mathrm{~kg}$ of maize flour (Clarke \& Rottger, 2006). If the mill can work 8 hours/day for 300 days/year, it will grind a total of 960 tonnes of maize flour per year using 7200 liters of fuel oil. Therefore, 562866 liters of fuel oil that can be obtained from waste plastics will be able to power a total of 78 hammer mills of $15 \mathrm{~kW}$ capacity. These 78 hammer mills will be able to grind approximately 74880 tonnes of maize annually.

\section{Conclusions and Recommendations}

Pyrolysis potentially offers prospects for sustainable way of solving plastic waste problem in Uganda. The quantity of plastic wastes generated in Wakiso; Kampala; Kibaale and Iganga; Arua and Kasese; Mubende and Mukono; Tororo and Rakai; and Hoima and Kabale districts was estimated approximately as $112,85,72,83,72$, 58 and 62 tonnes/day respectively. The total amount of fuel oil that can be generated from $545851 \mathrm{~kg}$ of plastic waste was quantified as $451419 \mathrm{~kg}$; which is equivalent to $582866 \mathrm{~L}$ under pyrolysis using an appropriate technology from major districts in Uganda. This potential can be used as a power source to run seventy eight 15 $\mathrm{kW}$ hammer mills to grind 74880 tonnes of maize flour per year. Likewise, it can be used to power 234 small portable threshers of 5-7 horse power to thresh 365000 tonnes of fresh paddy. Also, comparing the composition of MSW in SSA, the fraction of the organic wastes constitutes a higher percentage i.e. $59 \%$ on average. However, in the most developed world, such as U.S. the percentage of organic wastes in MSW is as low as $14.6 \%$, which is far below the value reported for SSA. $65-70 \%$ of MSW generated in developing countries ends up at landfill sites with only $10 \%$ recycled. This is always attributed to inadequate infrastructure and high capital costs. Even though, the Government of Uganda set a target to produce $30 \mathrm{MW}$ from MSW by the end of the year 2017, this seems unrealistic. This is because there are no infrastructure or whatsoever to accomplish such a target. For efficient solid waste management in SSA cities, waste minimization principles such as reduce, reuse and also energy recovery techniques such as pyrolysis, anaerobic digestion and composting that are sustainable should be encouraged.

\section{Acknowledgments}

This work was supported by the Mobility to Enhance Training of Engineering Graduates in Africa (METEGA) project and the Regional Universities Forum for Capacity Building in Agriculture (RUFORUM) (RU 2017 FAPA 175). Noble Banadda and Nicholas Kiggundu provided substantial contributions to the concept and design of the paper. Prosper Achaw Owusu drafted and critically revised the article for important intellectual content. All the authors proofread the final version of the paper for submission.

\section{References}

Achankeng, E. (2003). Globalization, Urbanization and Municipal Solid Waste Management in Africa. In 
African Studies Association of Australasia and the Pacific. 2003 Conference Proceedings-African on a Global Change (pp. 1-22). Retrieved from http://www.inclusivecities.org/pdfs/achankeng Globalization Urbanization and MSW Mgmt in Africa.pdf

Al-Salem, S. M., Lettieri, P., \& Baeyens, J. (2009). Recycling and recovery routes of plastic solid waste (PSW): A review. Waste Management, 29(10), 2625-2643. http://doi.org/10.1016/j.wasman.2009.06.004

Ali, S., Garforth, A. A., Harris, D. H., Rawlence, D. J., \& Uemichi, Y. (2002). Polymer waste recycling over "used" catalysts. Catalysis Today, 75(1-4), 247-255. http://doi.org/10.1016/S0920-5861(02)00076-7

Almeida, D., \& Marque, M. de F. (2015). Thermal and Catalytic Pyrolysis of Polyethylene Plastic Waste. Polimeros, 1-8. http://doi.org/http://dx.doi.org/10.1590/0104-1428.2100

Andrady, A. L., \& Neal, M. (2009). Applications and societal benefits of plastics. Philosophical Transactions of the Royal Society of London. Series B, Biological Sciences, 364(1526), 1977-1984. http://doi.org/10.1098/rstb.2008.0304

Bajus, M. (2011). Thermal cracking of mixtures of plastics and woody material. Petroleum and Coal, 53(1), 1-7.

Balakrishnan, R. B., Anand, K. P., \& Chiya, A. B. (2007). Electrical and electronic waste: a global environmental problem. Waste Management \& Research, 25(4), 307-318. http://doi.org/10.1177/0734242X07076941

Barnes, D. K., Galgani, F., Thompson, R. C., \& Barlaz, M. (2009). Accumulation and fragmentation of plastic debris in global environments. Philosophical Transactions of the Royal Society of London. Series B, Biological Sciences, 364(1526), 1985-1998. http://doi.org/10.1098/rstb.2008.0205

Bashir, N. H. H. (2013). Plastic problem in Africa. Japanese Journal of Veterinary Research, 61(SUPPL.), S1S11. http://doi.org/10.14943/jjvr.61.suppl.s1

Center for Sustainable Systems. (2015). Municipal Solid Waste (No. Pub. No. CSS04-15). Municipal Solid Waste Factsheet. Michigan. Retrieved from http://www.epa.gov/epawaste/nonhaz/municipal/

Chandrasekaran, S. R., Kunwar, B., Moser, B. R., Rajagopalan, N., \& Sharma, B. K. (2015). Catalytic Thermal Cracking of Postconsumer Waste Plastics to Fuels. 1. Kinetics and Optimization. Energy and Fuels, 29, 6068-6077. http://doi.org/10.1021/acs.energyfuels.5b01083

Chen, X., Geng, Y., \& Fujita, T. (2010). An overview of municipal solid waste management in China. Waste Management, 30(4), 716-724. http://doi.org/10.1016/j.wasman.2009.10.011

Clarke, B., \& Rottger, A. (2006). Small mills in Africa: Selection, installation and operation of equipment. Agricultural and Food Engineering Working Paper prepared for Food and Agriculture Organization of the United Nations. Rome. Retrieved from www.fao.org/docrep/016/j8482e/j8482e.pdf

Cleetus, C., Thomas, S., \& Varghese, S. (2013). Synthesis of Petroleum-Based Fuel from Waste Plastics and Performance Analysis in a CI Engine. Journal of Energy, 2013, 1-10. http://doi.org/10.1155/2013/608797

Demirbas, A. (2004). Pyrolysis of municipal plastic wastes for recovery of gasoline-range hydrocarbons. Journal of Analytical and Applied Pyrolysis, 72(2004), 97-102. http://doi.org/10.1016/j.jaap.2004.03.001

Deneve, D., Joshi, C., Samdani, A., Higgins, J., \& Seay, J. (2017). Optimization of an Appropriate Technology Based Process for Converting Waste Plastic in to Liquid Fuel via Thermal Decomposition. Journal of Sustainable Development, 10(2), 116-124. http://doi.org/10.5539/jsd.v10n2p116

Dhokhikah, Y., \& Trihadiningrum, Y. (2012). Solid Waste Management in Asian Developing Countries: Challenges and Opportunities. Journal of Applied Environmental and Biological Sciences, 2(7), 329-335. Retrieved from www.textroad.com

Dong, Y. (2011). Development of Waste To Energy in China; and Case Study of the Guangzhou Likeng WTE plant. Columbia University. Retrieved from http://www.seas.columbia.edu/earth/wtert/sofos/Dong_thesis.pdf.

El-Agroudy, S., Warith, M. A., \& El-Zayat, M. (2015). Solid Waste Management System and Green Economy. Retrieved from globalyoungacademy.net/activities/solid-waste-management-and-green-economy-2/

Eriksen, M., Lebreton, L. C. M., Carson, H. S., Thiel, M., Moore, C. J., Borerro, J. C., ... Reisser, J. (2014). Plastic Pollution in the World's Oceans: More than 5 Trillion Plastic Pieces Weighing over 250,000 Tons Afloat at Sea. PLoS ONE, 9(12), 1-15. http://doi.org/10.1371/journal.pone.0111913

European Commission. (2010). Being wise with waste: the EU's approach to waste management. Publications Office of the European Union. Luxembourg. Retrieved from 
http://ec.europa.eu/environment/waste/pdf/WASTE BROCHURE.pdf

Fauziah, S., \& Agamuthu, P. (2012). Trends in sustainable landfilling in Malaysia, a developing country. Waste Management \& Research, 30(7), 656-663. http://doi.org/10.1177/0734242X12437564

Gerrard, J., \& Kandlikar, M. (2007). Is European end-of-life vehicle legislation living up to expectations? Assessing the impact of the ELV Directive on "green" innovation and vehicle recovery. Journal of Cleaner Production, 15(1), 17-27. http://doi.org/10.1016/j.jclepro.2005.06.004

Giusti, L. (2009). A review of waste management practices and their impact on human health. Waste Management, 29(8), 2227-2239. http://doi.org/10.1016/j.wasman.2009.03.028

Grause, G., Matsumoto, S., Kameda, T., \& Yoshioka, T. (2011). Pyrolysis of mixed plastics in a fluidized bed of hard burnt lime. Industrial and Engineering Chemistry Research, 50, 5459-5466. http://doi.org/10.1007/s10163-011-0031-z

Guangyu, Y. (2010). Amounts and composition of municipal solid wastes. Encyclopedia of Life Support Systems (EOLSS), I, 1-8.

Guo, J., Guo, J., \& Xu, Z. (2009). Recycling of non-metallic fractions from waste printed circuit boards: A review. Journal of Hazardous Materials, 168(2-3), 567-590. http://doi.org/10.1016/j.jhazmat.2009.02.104

Hall, W. J., \& Williams, P. T. (2007). Separation and recovery of materials from scrap printed circuit boards. Resources, Conservation and Recycling, 51(3), 691-709. http://doi.org/10.1016/j.resconrec.2006.11.010

Hopewell, J., Dvorak, R., \& Kosior, E. (2009). Plastics recycling: challenges and opportunities. Philosophical Transactions of the Royal Society of London. Series B, Biological Sciences, 364(1526), 2115-2126. http://doi.org/10.1098/rstb.2008.0311

Jambeck, J. R., Geyer, R., Wilcox, C., Siegler, T. R., Perryman, M., Andrady, A., ... Law, K. L. (2015). Plastic waste inputs from land into the ocean in 2010. Science, 347(6223), 768-771. http://doi.org/10.1126/science.1260352

Joshi, C. A., \& Seay, J. R. (2016). An Appropriate Technology Based Solution to Convert Waste Plastic into Fuel Oil in Underdeveloped Regions. Journal of Sustainable Development, 9(4), 133-143. http://doi.org/10.5539/jsd.v9n4p133

Kaminsky, W., Predel, M., \& Sadiki, A. (2004). Feedstock recycling of polymers by pyrolysis in a fluidised bed. Polymer Degradation and Stability, 85, 1045-1050. http://doi.org/10.1016/j.polymdegradstab.2003.05.002

Kaminsky, W., \& Zorriqueta, I.-J. N. (2007). Catalytical and thermal pyrolysis of polyolefins. Journal of Analytical and Applied Pyrolysis, 79, 368-374. http://doi.org/10.1016/j.jaap.2006.11.005

Kasper, A. C., Berselli, G. B. T., Freitas, B. D., Ten??rio, J. A. S., Bernardes, A. M., \& Veit, H. M. (2011). Printed wiring boards for mobile phones: Characterization and recycling of copper. Waste Management, 31(12), 2536-2545. http://doi.org/10.1016/j.wasman.2011.08.013

Kinobe, J. R., Niwagaba, C. B., Gebresenbet, G., Komakech, A. J., \& Vinnerås, B. (2015). Mapping out the solid waste generation and collection models: The case of Kampala City. Journal of the Air \& Waste Management Association, 65(2), 197-205. http://doi.org/10.1080/10962247.2014.984818

Kluska, J., Klein, M., Kazimierski, P., \& Kardas, D. (2014). Pyrolysis of biomass and refuse-derived fuel performance in laboratory scale batch reactor. Archives of Thermodynamics, 35(1), 141-152. http://doi.org/10.2478/aoter-2014-0009

Komakech, A. J. (2014). Urban waste management and the environmental impact of organic waste treatment systems in Kampala, Uganda. Retrieved from http://pub.epsilon.slu.se/11558/

Komakech, A. J., Banadda, N. E., Kinobe, J. R., Kasisira, L., Sundberg, C., Gebresenbet, G., \& Vinnerås, B. (2014). Characterization of municipal waste in Kampala, Uganda. Journal of the Air \& Waste Management Association, 64(3), 340-348. http://doi.org/10.1080/10962247.2013.861373

Kumar, S., \& Singh, R. K. (2013). Thermolysis of High-Density Polyethylene to Petroleum Products. Journal of Petroleum Engineering, 2013, 1-7. http://doi.org/10.1155/2013/987568

Mazzanti, M., \& Zoboli, R. (2006). Economic instruments and induced innovation: The European policies on end-of-life vehicles. Ecological Economics, 58(2), 318-337. http://doi.org/10.1016/j.ecolecon.2005.06.008

Miezah, K., Obiri-Danso, K., Kadar, Z., Fei-Baffoe, B., \& Mensah, M. Y. (2015). Municipal solid waste characterization and quantification as a measure towards effective waste management in Ghana. Waste 
Management, 46, 15-27. http://doi.org/10.1016/j.wasman.2015.09.009

Nabukeera Madinah, A., \& Boerhannoeddin, R. N. B. R. A. (2014). Division Solid Waste Generation and Composition in Kampala Capital City Authority, Uganda: Trends and Management. IOSR Journal of Environmental Science, Toxicology and Food Technology (IOSR-JESTFT), 8(10), 57-62.

Narayana, T. (2009). Municipal solid waste management in India: From waste disposal to recovery of resources? Waste Management, 29(3), 1163-1166. http://doi.org/10.1016/j.wasman.2008.06.038

Okello, C., Pindozzi, S., Faugno, S., \& Boccia, L. (2013). Bioenergy potential of agricultural and forest residues in Uganda. Biomass and Bioenergy, 56, 515-525. http://doi.org/10.1016/j.biombioe.2013.06.003

Okot-Okumu, J., \& Nyenje, R. (2011). Municipal solid waste management under decentralisation in Uganda. Habitat International, 35(4), 537-543. http://doi.org/10.1016/j.habitatint.2011.03.003

Owusu, P. A., \& Banadda, N. (2017). Livestock Waste-to-Bioenergy Generation Potential in Uganda : A Review. Environmental Research, Engineering and Management, 10(3), 45-53. http://doi.org/10.5755/j01.erem.73.3.14806

Panda, A. K., Singh, R. K., \& Mishra, D. K. (2010). Thermolysis of waste plastics to liquid fuel: A suitable method for plastic waste management and manufacture of value added products - A world prospective. Renewable \& Sustainable Energy Reviews, 14, 233-248. http://doi.org/10.1016/j.rser.2009.07.005

PlasticsEurope. (2015). Plastics - the Facts 2015: An analysis of European plastics production, demand and waste data. Retrieved from http://www.plasticseurope.org/Document/plastics---the-facts-2015.aspx

Sarker, M., \& Rashid, M. M. (2013). Mixture of Waste Plastics to Fuel Production Process Using Catalyst Percentage Ratio Effect Study. International Journal of Environmental Engineering Science and Technology Research, 1(1), 1-19.

Sembiring, E., \& Nitivattananon, V. (2010). Sustainable solid waste management toward an inclusive society: Integration of the informal sector. Resources, Conservation and Recycling, 54(11), 802-809. http://doi.org/10.1016/j.resconrec.2009.12.010

Sharma, B. K., Moser, B. R., Vermillion, K. E., Doll, K. M., \& Rajagopalan, N. (2014). Production, characterization and fuel properties of alternative diesel fuel from pyrolysis of waste plastic grocery bags. Fuel Processing Technology, 122, 79-90. http://doi.org/10.1016/j.fuproc.2014.01.019

Singh, B., \& Sharma, N. (2007). Mechanistic implications of plastic degradation. Polymer Degradation and Stability, 93, 561-584. http://doi.org/10.1016/j.polymdegradstab.2007.11.008

Singh, R. K., \& Ruj, B. (2016). Time and temperature depended fuel gas generation from pyrolysis of real world municipal plastic waste. Fuel, 174, 164-171. http://doi.org/10.1016/j.fuel.2016.01.049

Smink, C. K. (2007). Vehicle recycling regulations: lessons from Denmark. Journal of Cleaner Production, 15(11-12), 1135-1146. http://doi.org/10.1016/j.jclepro.2006.05.028

Thompson, R. C., Moore, C. J., vom Saal, F. S., \& Swan, S. H. (2009). Plastics, the environment and human health: current consensus and future trends. Philosophical Transactions of the Royal Society of London. Series B, Biological Sciences, 364(1526), 2153-2166. http://doi.org/10.1098/rstb.2009.0053

Troschinetz, A. M., \& Mihelcic, J. R. (2009). Sustainable recycling of municipal solid waste in developing countries. Waste Management, 29(2), 915-923. http://doi.org/10.1016/j.wasman.2008.04.016

Tukahirwa, J. T., Mol, A. P. J., \& Oosterveer, P. (2010). Civil society participation in urban sanitation and solid waste management in Uganda. Local Environment, 15(1), 1-14. http://doi.org/10.1080/13549830903406032

UBOS. (2010). 2010 Statistical Abstract. Uganda National Statistics. Retrieved from www.ubos.org/onlinefiles/uploads/ubos/.../2010StatAbstract.pdf

UNEP. (2009). Converting waste plastics into a resource: Compendium of Technologies. Osaka. Retrieved from www.unep.or.jp/Ietc/Publications/spc/WastePlasticsEST_Compendium.pdf

UNEP. (2014). Valuing Plastics: The Business Case for Measuring, Managing and Disclosing Plastic Use in the Consumer Goods Industry. Retrieved from www.unep.org/pdf/ValuingPlastic/

van Gevelt, T., Holzeis, C. C., Jones, B., \& Safdar, M. T. (2016). Insights from an energy poor Rwandan village. Energy for Sustainable Development, 32, 121-129. http://doi.org/10.1016/j.biombioe.2007.09.001 
Veit, P. G., Excell, C., \& Zomer, A. (2011). Avoiding the resource curse: spotlight on oil in Uganda. Retrieved from www.wri.org/sites/default/files/avoiding_the_resource_curse.pdf

Wong, S. L., Ngadi, N., Abdullah, T. A. T., \& Inuwa, I. M. (2015). Current state and future prospects of plastic waste as source of fuel: A review. Renewable and Sustainable Energy Reviews, 50, 1167-1180. http://doi.org/10.1016/j.rser.2015.04.063

Yamane, L. H., de Moraes, V. T., Espinosa, D. C. R., \& Tenório, J. A. S. (2011). Recycling of WEEE: Characterization of spent printed circuit boards from mobile phones and computers. Waste Management, 31(12), 2553-2558. http://doi.org/10.1016/j.wasman.2011.07.006

Zhang, D. Q., Tan, S. K., \& Gersberg, R. M. (2010). Municipal solid waste management in China: Status, problems and challenges. Journal of Environmental Management, 91(8), 1623-1633. http://doi.org/10.1016/j.jenvman.2010.03.012

\section{Copyrights}

Copyright for this article is retained by the author(s), with first publication rights granted to the journal.

This is an open-access article distributed under the terms and conditions of the Creative Commons Attribution license (http://creativecommons.org/licenses/by/4.0/). 